Journal of Social and Development Sciences

Vol. 3, No. 5, pp. 161-166, May 2012 (ISSN 2221-1152)

\title{
Gender Diversity and Firm Performance: Evidence from Pakistan
}

\author{
Hammad Hassan Mirza1 ${ }^{1}$ Shahid Mahmood ${ }^{1}$, $S$ Sumaira Andleeb², Farzana Ramzan ${ }^{1}$ \\ 1University of Sargodha, Pakistan \\ ${ }^{2}$ Beaconhouse School System Sargodha, Pakistan \\ *sumaira_malhi0303@yahoo.com
}

\begin{abstract}
Gender diversity and firm performance, is among the new but challenging topics of research in management sciences. Many researchers have studied the role of gender diversity in enhancing firms' performance in developed economies (see for example, Dwyer et. al, 2003; and Kang et al, 2010). Existing literature on this subject is rare in emerging economies and to the best of author's knowledge; this is the first study on relationship of gender diversity and firm's performance in Pakistani context. Present study focuses on the impact of presence of female directors on corporate performance using a sample of 395 listed nonfinancial companies of Karachi Stock Exchange (KSE) Pakistan from 2004 to 2009. Estimated results indicate that ratio of female directors is negatively related with firm performance.
\end{abstract}

Key words: Ratio of female directors, ROA, ROE, Gender diversity, Pakistani firms

\section{Introduction}

Every society has its own culture, norms and social values and according to these patterns, women are placed at different social, moral and authoritative status. A similarity in almost all societies is the sense of superiority in men, resulting in male dominant societies. Narrowing the focus to management rather corporate management, the female segment is very small in top management around the globe, as it is a common belief that women lack decision power, are emotional, less rational and therefore do not have strategic mind and vision needed for survival in the corporate world. Research on gender and business ethics suggests that women are more ethical than men in attitudes and behaviors (Beltramini et. al. 1984). Companies in which number of female directors are more than three, perform better in terms of corporate governance and financial performance. Empirical research also supports social reluctance regarding award of top corporate managerial positions to women, resulting in a very negligible number of women on the top in emerging economies. For instance, recent international survey indicates that, Pakistan, India, Japan and Netherland are the bottom five nations, having least fraction of women, working on top managerial positions (Antonio, 2007). Members of board of directors fetch a mass of talents to the boardroom table. Becker (1964) referred it as human capital which represents the exclusive talents of the director from diverse training, experience and knowledge backgrounds. According to Markarian and Parbonetti (2007) this human capital can be used to explain the strategy which firm uses to deal with complex situations and take strategic decisions (Baysinger \& Zardkoohi, 1986; Dunn, 2011; Hillman et al., 2000, 2002; Singh et al., 2008). Regarding role of gender in board of directors, this is commonly known that women tend to have different professional experiences as compared to their male partners (Nielsen \& Huse, 2010) and it is also evident that female directors tend to hold advance degrees and shift from one firm to another more faster than their male counterparts (Hillman et al., 2000). For instance, Singh et al (2008) has observed that British female directors normally have degree of MBA with working experience internationally. However, exactly inverse is observed in developing economies where female are not much encouraged to participate in decision-making process. Dynamics contributing to this dilemma are common believes regarding the aggressiveness, risk aversion, lack of confidence and mental instability in female instinct. It is generally assumed that first priority of women is her family and home, ranking official duties at a secondary priority depending upon the financial stress and genuine commitment is missing most of the time. There are also some invisible socially built barrier to keep women in inferior positions. All these factors result in slow progression of female segment towards top managerial positions in both developed and developing countries. 
The Economic thrust to utilize the female segment of work force and some examples of stunning female performances on top managerial positions are changing the views of people with passage of time but still women are not considered as equal competitors of men. Some have suggested legislations to fix the proportion of women in top management as Danish corporate legislation has made a mandatory female share of $40 \%$ in top management. For the rest of world the female ratio in top management is still negligible. Besides its weak side, gender diversity in corporate board and top positions has certain benefits. With difference in experience, mode of thinking and psychology, diverse top management or board of directors can take up better projects resulting in better outcomes. However, beauty of this diversity can be spoiled in the presence of gender politics and grouping, resulting in wastage of organizational resources. It is therefore, important to explore the actual role of gender diversity at corporate level. Most of the previous studies (see for example: Bilimoria and Piederit, 1994; Kesner, 1988; Peterson and Philpot, 2006) on board composition and gender diversity are descriptive, where researchers have investigated the performance of entire committee at a particular point of time. This approach, besides its positive aspects, is flawed due to its weakness in capturing impact of gender diversity on firm performance. Present study tries to find out the impact of number of female members, in top management, on corporate performance. Although in some companies female are on top managerial positions and in board of directors, but most of them are running their family businesses where education, skills and abilities are not considered. In family businesses, they do not face competition to reach on the top positions. There are certain factors contributing to encouragement of women in corporate arena. First factor is better and encouraging environment of business schools and improved educational policies of government due to which more women are graduating as compare to men. Second factor, is more innovation of present time. This leads the investors to initiate new business resulting in more prospects for women to work and prove their abilities and reach on highest positions in managerial hierarchy. To the best authors knowledge this is the very first study conducted on role of gender diversity in enhancing firm performance in Pakistan.

\section{Literature Review}

Gender diversity and firm performance has remained under consideration by a number of prominent researchers for last few decades. A number of studies have been carried out in developed countries to find out the impact of gender effect on firm performance. Results of these studies are mixed in nature. There is no consensus or conclusive decision on favorable or unfavorable impact of gender diversity on firm performance. Farrell \& Hersch (2005) found that women tend to serve on better performing firms. They also documented insignificant abnormal returns on the announcement of a woman added to the board. Rather than the demand for women directors being performance based, results suggested corporations responding to either internal or external calls for diversity. Smith et. al. (2006) found that the proportion of women in top management jobs tends to have positive effects on firm performance, even after controlling for numerous characteristics of the firm and direction of causality. They use sample of 2500 Danish firms and found that presence of female in top management, firm performance varies from none to positive in relation, and those female directors, which are selected by staff, have positive effect on firm performance. Their results show that the positive effects of women in top management strongly depend on the qualifications of female top managers. Dezso and Ross (2008) studied effectivness of female as senior managers, using Tobin's Q as performance yardstik. A positive association in firm performance and female participation below CEO level was found in innovative organizations. Their results showed potential competetive advantage for identification and development of female managerial talent. Similarly, Campbell and Vera (2008) studied the Spanish firms using panel data analysis, they found that gender has a positive effect on firm value and that the opposite causal relationship is not significant. They concluded that investors in Spain do not penalize firms, which increase their female board membership, and that greater gender diversity may generate economic gains as stock price shows a positive effect by announcement of female directors. Adams and Ferreira (2009) found that female director have a significant impact on board inputs and firm outcomes. Their results showed that gender diverse boards allocate more effort to governaance and monitoring because women are regular and punctual as compare to men but this thing not gives significant result that by increasing women ratio as directors will show positive association with performance measure. Hussein and Kiwia (2009) examined the relationship between female board members and firm performance for a panel of 250 US firms over the years 
2000 and 2006. On one hand, their results found no positive and significant relationship between performance measures of ROA, Tobin's $Q$ ratio, gender influence and gender mix.

On the other hand, the Shannon index, which measures the level of female representation inside the boardroom, showed positive and significant relationship between gender and firm value. Therefore, it is established that different measures may give different results. Using the financial event study method. Kang et. al. (2010) has found that investors generally respond positively to the appointment of women directors in Singaporean firms. This study not only tests the theory of gender diversity in an Asian context but also examines whether investors react systematically to the different positions that women directors hold on corporate boards, a question that has received little attention in prior studies. On the other hand, Jurkus et. al. (2011) in their study investigates gender diversity among the top managers of Fortune 500 firms and its effect on agency costs. The study finds that firms with a greater percentage of female officers present lower agency costs but that the negative relation is not robust when considering the endogeneity of diversity. The results suggest that increasing diversity in management can have beneficial effects for firms where strong external governance is absent. Using data of Norwegian firms, Ahern and Dittmar (2011) argued that by increasing female ratio as director stock value goes down leaving negative effect on firm performance which is opposite to Campbell and Vera (2008). In their opinion female directors are not expert and senior as male directors are. Due to this diversity firm face losses and to fulfill its expenses company borrow from different sources, so operating costs increases, while profit and firm performance decreases. Consequently, the Tobin's $\mathrm{Q}$ declines which is a significant measure of firm performance. Using a sample of US firms Robb and Watson (2011) used logitudinal data of U.S new ventures to estabilish whether potential differences in performances of female and male owened firms vanishes if appropriate performance measures are used. Using ROA, Sharp ratio, univariate and multivariate test results confirmed that there is no difference in performance of female and male owned venures. Dobbin and Jung (2011) observed the effect of corporate board gender diversity on stock performance and concluded that the organization with board diversity shows negative or neutral results with different performance measure such ans ROA, Tobin's q and cumulative stock returns. In such cases investors become biased and avoid to invest in firms having female directors which leads to a decline in stock prices. It is evident from above discussion that gender diversity playes an important role in determining firm performance. It is however, unfortunate that the role of gender diversity in board of directors has been ignored in developing economies where gender discrimination is wide spread cultural phenomenon. The empirical evidence on impact of presence of female directors on firm's performance in emerging economies like Pakistan is virtually non existant. Present study is an attempt to address this issue in contaxt of listed non financial companies of Pakistan.

\section{Methodology}

In the light of existing literature, present study focuses on the impact of presence of female directors in top management of Pakistani firms on firm performance. For this purpose the data has been collected from two main sources, state bank of Pakistan's published financial statements and, 'Business Recorder's' website to find out market value of the company year end. Sample period was six year (2004-2009), with data of 395 listed companies. Sample included companies from, textile, sugar, telecommunication, engineering, chemical and paper and board industry. Total observations for sample time and companies were 2786. After omitting observations with missing values, final observations for study remained 572.

The Model: Statistical Package for Social Sciences (SPSS) was applied in the process of data input and compilation. In order to test the research hypothesis, we followed the linear regression model used by Smith et. al. (2006) and Hussein and Kiwia (2009).

$$
\boldsymbol{P}_{i t}=\boldsymbol{\beta}_{1} \boldsymbol{X}_{i t}+\boldsymbol{\beta}_{2} \boldsymbol{F C E O _ { i t }}+\boldsymbol{\beta}_{3} \boldsymbol{F B M} \boldsymbol{M}_{i t}+\boldsymbol{e}_{i t}
$$

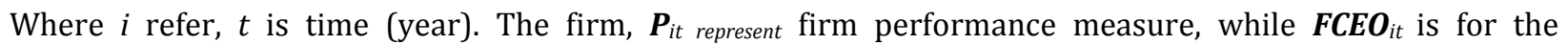
proportion of female executives, $\boldsymbol{F} \boldsymbol{B} \boldsymbol{M}_{i t}$ stands for female board members and $\boldsymbol{\beta}_{2}$ and $\boldsymbol{\beta}_{3}$ are parameters. The $\boldsymbol{X}_{\mathrm{it}}$ is a vector of explanatory and $\boldsymbol{e}_{i t}$ is the error term.

In our research we focused on ROA and ROE as dependent variable and ratio of female directors and total liability to total assets as independent variable. So we refined model as follows;

$$
\boldsymbol{P}_{i t}=\boldsymbol{\beta}_{0}+\boldsymbol{\beta}_{1} \boldsymbol{R} \boldsymbol{F} \boldsymbol{D}_{i t}+\boldsymbol{\beta}_{2} \boldsymbol{L V G} \boldsymbol{G}_{i t}+\boldsymbol{e}_{i t}
$$


Where $\boldsymbol{R F D}_{i t}$ represent ratio of female directors in year $\mathrm{t}$ and $\mathrm{LVG}_{i t}$ represent ratio of liability to assets of a company at time. $\boldsymbol{P}_{i t}$ represent return on assets (ROA) and return on equity (ROE) which are dependent variables of firm performance.

\section{Results}

Statistics covering different issues of results are summarized as follows. Table 1 provides an insight on the descriptive statistics of the data used for this study.

Table 1: Descriptive Results

\begin{tabular}{llllll}
\hline & N & Min & Max & Mean & Std. Dev \\
\hline ROA & 572 & -123.20 & 82.50 & 1.814 & 13.793 \\
ROE & 572 & -943.20 & 441.50 & -4.104 & 75.96 \\
RFD & 572 & .17 & 1.00 & .3477 & .1884 \\
LVG & 572 & .01 & 0.91 & .6182 & .227 \\
\hline
\end{tabular}

The above table shows that ratio of minimum female directors in sample companies is $17 \%$ percents. Most of the companies in Pakistan have maximum number of directors equal to 7 with some exceptions where number of directors is equal to 8 or more. There is only 1 company in the sample with all female directors. Total 572 firm year observations have been included in the sample for estimation of results.

Table 2: Correlation

\begin{tabular}{llll}
\hline & ROA & RFD & LVG \\
\hline ROA & 1.000 & -.120 & -.220 \\
RFD & -.120 & 1.000 & -.129 \\
T Lib/T.assets & -.220 & -.129 & 1.000 \\
ROE & N/A & -.108 & -.191 \\
\hline
\end{tabular}

Table 2 gives correlations among dependent variables ROA and ROE and independent variables RFD and LVG. This correlation shows association between these variables. From this table it is clear that in Pakistan the performance of firm and female directors have negative association as correlation shows negative association, which is supported by previous studies, which show that presence of female on top management does not support firm performance. So we can generalize our result overall the economy other than emerging economies or economy of Pakistan as the previous studies support these results. The higher correlation is $22 \%$ between ROA and T Lib/TAssets and highest correlation between independent variables is $-19.1 \%$, which is an indication that there is no problem of multicollinearity attributed to the data.

Table 3: OLS Regression Estimates

\begin{tabular}{|c|c|c|c|c|}
\hline & \multirow{2}{*}{$\begin{array}{l}\text { ROA } \\
\text { B }\end{array}$} & \multicolumn{2}{|r|}{ ROE } & \multirow[b]{2}{*}{ Std. Error } \\
\hline & & Std Error & B & \\
\hline \multirow[t]{2}{*}{ Const. } & 14.627 & 2.029 & 57.820 & 11.271 \\
\hline & [7.211] & $(0.000)$ & [5.130] & $(0.000)$ \\
\hline \multirow[t]{2}{*}{ RFD } & -11.070 & 2.983 & -54.379 & 16.573 \\
\hline & {$[-3.711]$} & $(0.000)$ & {$[-3.281]$} & $(0.001)$ \\
\hline \multirow[t]{2}{*}{ LVG } & -14.501 & 2.465 & -69.586 & 13.697 \\
\hline & [-5.882] & $(0.000)$ & {$[-5.080]$} & $(0.000)$ \\
\hline R-Sq. & .071 & & 0.055 & \\
\hline Adj. R Sq. & .051 & & 0.051 & \\
\hline F-Stat & 21.736 & & 16.415 & \\
\hline Sig. F & 0.000 & & 0.000 & \\
\hline Durbin Watson & 1.418 & & 1.888 & \\
\hline
\end{tabular}

Parentheses show [t stat] and P-Value] 
In the above table 3 value of Beta tells us about the relation, the ratio of female directors in an organization and its effect on ROA and ROE of the firm. Dezso and Ross (2008) argued that women working as CEO or on top position either have negative or neutral relation, our result are consistent with the study of Dezso and Ross (2008). The R square values are very low for ROA and ROE, which is because female directors and LVG (TLib/TAst) are not only measures of firm performance. There are many factors affecting the performance of industry including systematic and unsystematic risk factors such as monetary policy of any economy, exchange rate, inflation rate, industry risk and many more factors. As one of the assumptions of linear regression model tell us that if the value of Durbin-Watson is less than 2 then our model is fit. Durbin-Watson used to detect the presence of autocorrelation. So our results explain this fact that the variable has no problem of autocorrelation. For our both results on ROA and ROE Durbin-Watson value is less than 2 so we are sure about the fitness of model. Variance inflation factor (VIF) value in this study is 1.017, also proves that our model fulfill the assumption of regression model and have no effect of multicollinearity as its value is closer to 1 , which is very low value for presence of multicollinearity in an ordinary least squares regression analysis. This VIF explains the strength of the standard error, compared with what it would be if that variable were uncorrelated with the other independent variables in the equation, as this value is negligible so we can say that these variables are uncorrelated.

\section{Conclusion}

In this paper, we investigated the impact of females' directors on firm performance measuring factors such as return on assets (ROA) and return on equity (ROE). We applied different approaches to alleviate endogeneity and autocorrelation factors. Our major focus was on Pakistan's economy and we took all data from firms listed in KSE, Pakistan. Results shows consistency with the previous study that if females are working on top of the firm it will give negative sign to the investors and leads the firm performance toward decline, as Smith et. al. (2006) , Ahern \& Dittmar (2011) proved that presence of female shows either negative or neutral result on firm performance. The reason is may be believe of people that women are emotional, aggressive, risk averse, less confident and not well educated and some invisible barriers, which are built by society to keep women in lower position.

\section{Reference}

Adams, R. B. \& Ferreira, K. (2009). Women in the boardroom and their impact on governance and performance. Journal of Financial Economics, 94, 291-309.

Ahern, K. R. \& Dittmar, A. K. (2010). The changing of the boards: The value effect of a massive exogenous shock, working paper, Ross School of Business, University of Michigan.

Baysinger, B. D. \& Zardkoohi, A. (1986). Technology, residual claimants, and corporate control. Journal of Law, Economics, and Organization, 2, 339-349.

Becker, G. S. (1964). Human Capital, 1st ed. (New York: Columbia University, Press for the National Bureau of Economic Research).

Bilimoria, D. \& Piederit, S. K. (1994). The relationship between women corporate directors and women corporate officers. Journal of Management Issues, 18(1), 47-61.

Campbell, K. \& Minguez-Vera, A. (2008). Gender diversity in the boardroom and firm financial performance. Journal of Business Ethics, 83, 435-51.

Carter, D. A., Simkins, B. J. \& Simpson, W. G. (2003). Corporate Governance, Board Diversity and Firm Value. The Financial Review, 38, 33-53.

Dezso, C. L. \& Ross, D. G. (2008). Girl power': Female participation in top management and firm performance. Social Science Research Network. http://ssrn.com/abstract=1088182

Dobbin, F. \& Jiwook, J. (2011). Corporate Board Gender Diversity and Stock Performance: The Competence Gap or Institutional Investor Bias? North Carolina Law Review, 89(3), 809-838.

Dwyer, S., Richard, O. C. \& Chadwick, K. (2003). Gender Diversity in Management and Firm Performance: The Influence of Growth Orientation and Organizational Culture. Journal of Business Research, 56(12), 1009-1019.

Dobbin, F. \& Jiwook, J. (2011). Corporate Board Gender Diversity and Stock Performance: The Competence Gap or Institutional Investor Bias? North Carolina Law Review, 89(3), 809-838. 
Dunn, P. (2011). Diversity in the boardroom: Breaking the gender barrier in Canada. Journal of Management \& Governance, forthcoming.

Farrell, K. A. \& Hersch, P. L. (2005). Additions to Corporate Boards: The effect of gender. Journal of Corporate Finance, 11, 85-106.

Hillman, A. J., Cannella, A. A. \& Harris, I. C. (2002). Women and radical minorities in the boardroom: How do directors differ? Journal of Management, 28(6), 747-763.

Hillman, A. J., Cannella A. A. \& Paetzold, R. L. (2000). The resource dependency role of corporate directors: Strategic adoption of board composition in response to environmental change. Journal of Management Studies, 37, 235-255.

Hussein, K. \& Kiwia, B. (2009). Examining the Relationship between Female Board Members and Firm Performance-A Panel Study of US Firms. African Journal of Finance and Management, 4(2).

Jurkus, A. F., Park, J. C. \& Woodard, L. S. (2010). Women in top management and agency costs, Journal of Business Research, 7-14.

Kesner, I. F. (1988). Directors' characteristics and committee membership: An investigation of type, occupation, tenure and gender. Academy of Management Journal, 31, 66-84.

Kang, E., Ding, D. K. \& Charoenwong, C. (2010). Investor Reaction to Women Directors. Research Collection Lee Kong Chian School of Business (Open Access). Paper 1761.

Markarian, M. \& Parbonetti, A. (2007). Firm complexity and board of director composition. Corporate Governance: An International Review, 15(6), 1224-1243.

Nielsen, S. \& Huse, M. (2010). The contribution of women on boards of directors: Going beyond the surface. Corporate Governance: An International Review, 18(2), 136-148.

Peterson, C. A. \& Philpot, J. (2006). Women's roles on U.S. Fortune 500 boards: Director Expertise and Committee Memberships. Journal of Business Ethics, 72, 177-196.

Singh, V., Terjesen, S. \& Vinnicombe, S. (2008). Newly appointed directors in the boardroom: How do women and men differ? European Management Journal, 26(1), 48-58.

Smith, N., Smith, V. \& Verner, M. (2006). Do women in top management affect firm performance? A panel study of 2,500 Danish firms. International Journal of Productivity and Performance Management, 55, 569-593. 